\title{
Limitations of Military Power to Counter a Rising China
}

\author{
Brendan M. Potter ${ }^{1}$
}

\begin{abstract}
Research finds that a heavy reliance on unaccompanied military deterrence with China is an ineffective solution. The U.S. lacks the requisite industrial power to replicate the winning conditions of its victory in the Pacific during World War Two. Untried developments in military technology create an unacceptable level of uncertainty at the outset of a conflict between two major powers. The study concludes that a more multidimensional approach must be increasingly emphasized by the U.S., incorporating other instruments of national power. The U.S. must increasingly foster security partnerships with allies, rely on the normative pressures from the international community via institutions, and adjust the form and focus of its own military to optimize the efficiency of existing forces without resorting to increased defense spending. Lastly, the U.S. must find common ground with China, reversing feelings of alienation and bullying that influence China to disregard the concerns of other nations.
\end{abstract}

Keywords: military strategy, military technologies, security policy, naval security

\section{Introduction}

I f many Americans were asked to think about their own country's navy fighting a modern conflict in the $\mathrm{Pa}$ cific Ocean, recollections of a victorious American campaign against Imperial Japan would surely come to mind. It is a forgivable mistake. The prospect of war is often unsettling, and such memo- ries of comfort would be attractive. For those who do not fear being harmed by it, assertive and confident feelings can be easy to entertain. Images of Japanese aircraft carriers burning not long after American entrance to the war, dramatic clashes of surface combatant guns with the ease of hindsight bias, and a long chain of island-hopping Marines winning victories all the way to the Japa-

1 The author would like to acknowledge Dr. William Boettcher of the School of Public and International Affairs at North Carolina State University for tremendous support in reviewing this manuscript and providing critical feedback during its development. 
nese islands themselves - these could all provide ready reassurance to that troublesome scenario. The war bond selling picture of the flag being raised on Iwo Jima is now a national icon, enshrined in the American identity and imagination. But would another naval conflict in the Pacific Ocean yield similar, patriotism-swelling experiences? If you are attached to these nostalgic visions, this study is meant for you.

Could the United States bounce back from a crippling strike against its naval forces as it did after the attack on Pearl Harbor? Could the United States grow a stronger military under the sustained losses of a protracted naval campaign against a peer threat? Would the United States need to strike first to assure victory? Can we even have reasonable certainty about the way in which any naval war between major, naval powers would unfold in the modern era? This study examines the limitations of the United States military to optimistically counter China in a predominantly unilateral solution. While maintaining the need for a strong military as a vital component to American foreign policy, it finds a need to place stronger emphasis on alternative solutions in this case.

\section{Expectations}

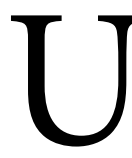

nilateral, military power from the United States is a doubtful proposition in this new circumstance. The United States must increasingly rely on 1) alliances, 2) developing military partnerships, 3) normative pressure from the international community via international institutions, 4) optimization of its existing military forces without increased defense spending, and 5) direct diplomacy in order to counter aggression and expansion from China. The United States is unable to rely heavily on unilateral, military deterrence because it 1) lacks the requisite industrial power to replicate its victory in the Pacific during World War Two, and 2) there is an unacceptable level of uncertainty in a theoretical naval conflict owing to the prevalence of untried military technologies.

\section{Methodology}

This study does not seek to examine the roots or nature of the disputes between China and the United States and the international community. How these disagreements have manifested and how actors have sought resolution is largely beyond the scope of research. Instead, this study is primarily concerned with assessing the limitations of unilateral, military power in the United States as an effective deterrent. It does so with the main conclusion of advocating for alternative approaches to the United States' handling of the Chinese security problem.

When political science examines armed conflicts or their potential between nations, it is remiss where it ignores or sidesteps an attentive examination of the actual military power of actors. Doubtless, many other factors are relevant to the questions of conflict, which need not be diminished. Much 
important research in the field is given over to those factors. However, these are necessarily limited in scope. The main focus of this study is exploring the inadequacies of military power as a reliable answer to the security problems of a rising China. As such, military science is especially relevant in this study.
Military science is nested deeply within the field of political science and can thus be regarded in some ways as near to the core of questions regarding security (Shultz, 2012). This illustration encapsulates the relationship between the disciplines:

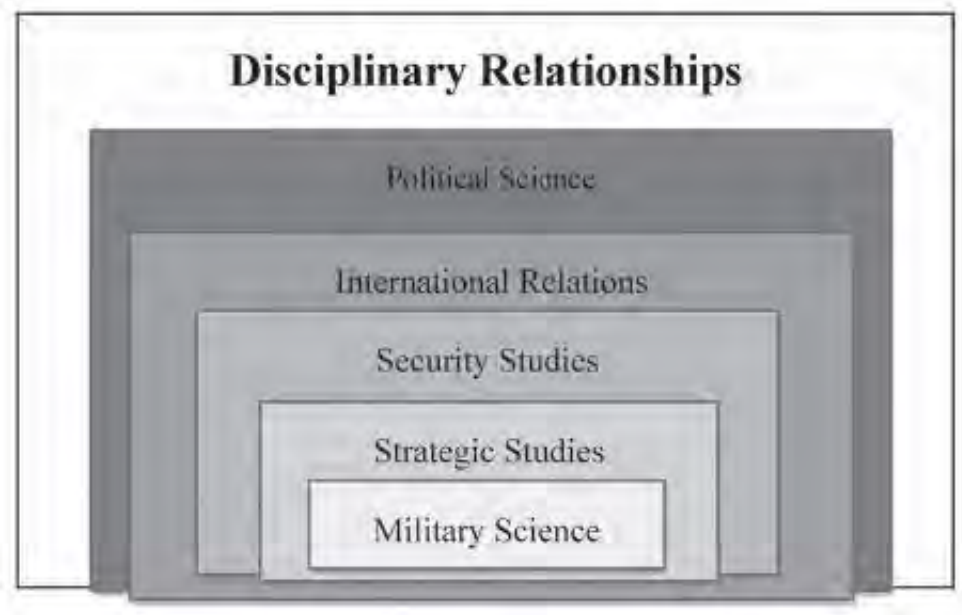

(Shultz, 2012, p. 8)

This depiction is in no way indicative of a consensus or standardization in thought across the field (Shultz, 2012, p. 7). To the contrary, there is much disagreement about the disciplinary relationships and their individual importance therein (Shultz, 2012, p. 7). What is clear is that, while military science resides close to the ground, and much of political science views macro conditions from far above, a realistic understanding must still be able to at least discern the features of the ground in sufficient detail to ascertain some navigable meaning of the landscape.

Current, historical, and proposed force structures and capacities will be examined from a variety of sources to determine some approximation of not only military power, but the larger trends of direction that military power has taken. In the scope of this study, force structure will predominantly be limited to quantities of different types of naval vessels, and some general descriptions of them. Capacity, the ability to produce and maintain ships, will be examined across a historical timeline. This is not intended to be a comprehensive assessment of military power but will draw sufficient analysis to identify limitations of military power in support of the hypotheses.

The use of historical case study is another important feature of the methodology. In seeking some corollary ex- 
perience against which to compare a theoretical, modern naval conflict, we must return to the previous, major one. Usefully, this previous naval conflict was predominantly between the United States and a peer, Asian naval power across the Pacific Ocean. The foundations that facilitated American success will be contrasted with modern conditions. Lastly, this study acknowledges the condition of nuclear arms and the dangers that they impose but does not focus on the nuclear component of a potential conflict with China. Rather, this study treats conventional conflict below the nuclear threshold as the hypothetical scenario, and acknowledges the nuclear question only as a supporting consideration to reinforce the arguments against unilateral, military measures as a solution to the security problems posed by China in the South China Sea.

\section{Literature Review}

I $\mathrm{n}$ examining the shifting attitudes of the United States military, this study relies on current, official documents expressing reforms and visions for new military direction. Security strategy development is a layered process in which lower echelons of strategy are nested within those of the higher authorities. The construction of strategy begins at the executive branch level with the $\mathrm{Na}$ tional Security Strategy (NSS), the unclassified portions of which are usually tantamount to a political statement, but which guide the construction of subordinate strategies. Subsequently, the Secretary of Defense publishes a National Defense Strategy (NDS), much of which is unclassified, especially in summaries. At the highest levels of uniformed authority, the Joint Chiefs of Staff (JCS) publish the National Military Strategy (NMS). The separate military branches use these guidelines to publish their individual service strategies, which have different names for each service.

This study will examine the unclassified portions of these foundational documents: the NDS (DoD, 2018), and the NMS (JCS, 2018). In the case of the executive NSS, the Trump administration's NSS will be examined for recent context (Trump, 2017). Since the Biden administration's NSS is still in development at the time of this study's writing, the Interim National Security Strategic Guidance will be used (Biden, 2021). It is important to note that revisions to the subordinate strategies will likely be forthcoming in the near future. In the case of the separate military branches, only the Commandant's Planning Guidance from the Marine Corps will be examined, because it is especially drastic in the changes that it makes to force structure and focus (HQMC, 2019).

John Mearsheimer is a prolific, political scientist who is famous for his brand of realism in international relations, known as offensive realism. Mearsheimer has gained much attention and notoriety for his views advocating that states seek hegemony as an answer to the problem of security. This study's advocacy for an increased reliance on diplomacy, alliances, and international institutions directly contradict the theories of Mearsheimer, yet his analysis will nonetheless be important to this study. Mearsheimer's (2001) 
cornerstone work The Tragedy of Great Power Politics, which is the foundation in which he outlines his theory of offensive realism, will be called upon to recognize counterarguments and to back assertions made in this study of the relevance of naval power in the case of a Pacific island conflict.

In order to obtain a picture of the current state of the United States military's recent developments and problems, a variety of defense focused news outlets will be referenced. In a few cases, I will insert my personal experience. For supporting scholarly thought on the contemporary problem set, this study will rely on various think tanks and venues for analysis such as the U.S. Naval Institute, the Center for Global Security Research with Lawrence Livermore National Laboratory, and War on the Rocks. It will be supported by comprehensive analysis by sources such as the Center for Strategic and International Studies and the RAND Corporation.

\section{Recognition of the Threat}

1 There are familiar signs today from a rising China, with a massively expanding naval arm, engaged in acts of expansion and assertion that merit serious security concerns. In 1941, the United States was the victim of a surprise, naval attack that brought it into a major conflict. Yet, shortly after the end of World War One, American policy makers had already recognized Imperial Japan as the main security threat that the United States faced, and for the same reasons that it is today concerned with China (DoS, n.d.). The emphasis that the United States places on the military threat of an expanding China is clear. All of the foundational documents of strategy, from the White House through the Secretary of Defense to the Joint Chiefs of Staff and the military services demonstrate a clear recognition of the threat. While China's neighbors raise increasing alarm over the sometimes-unusual encroachments of China, the United States takes notice and has become heavily involved in the region (McCarthy, 2021).

The works of John Mearsheimer could be a source of potential criticism from those who believe in the limited utility of naval power, and thus dispute both the seriousness of a rising Chinese naval power and an emphatically naval response. This author's work is influential in its modern rebranding of realism and affects strategic thought and policy makers alike. Mearsheimer (2001) is highly critical of naval power as a means of independently coercing a great power to another's will. Advocating for the primacy of land-based power, Mearsheimer (2001) flatly states that "neither independent naval power nor strategic airpower has much utility for winning major wars" (p. 86). However, Mearsheimer (2001) recognizes the case of naval action against Imperial Japan during World War Two to be an exceptional case for the success and relevance of naval power. Specifically, he refers to naval power aimed against the Pacific power as "the only case in which a blockade wrecked a rival's economy, causing serious damage to its military forces" and "the only case ... of successful coercion” (p. 92). 
This is important because even those critical of naval power as a coercive instrument must recognize the uniqueness of the location of the Pacific Ocean and the maritime nature of disputes with China in the South China Sea as evidence for a very strong, if not central, role for naval forces in countering China. Moreover, Mearsheimer's subordinate role of troop transport raises security concerns for China's developing ability to use naval capabilities to project land power to neighboring territories, as Imperial Japan did throughout the islands of Southeast Asia. There is some merit to Mearsheimer's critiques. Historically, land power has been the primary coercive instrument in the majority of conflict cases. However, even in the case of a Chinese threat today, there is a clear recognition by the United States for the need to integrate naval, land, and air forces. It just so happens that in this case, independent naval forces have disproportionate importance.

General David Berger (2020), the Commandant of the Marine Corps, has spoken about the changes that confrontation with a peer competitor has brought to the military services. Importantly, there is clear, high level recognition that the United States Navy and Marine Corps have not had a need to work together closely since the close of World War Two (Berger, 2020). This is owing to 1) the wide margin of power that the United States has enjoyed since the end of World War Two, and 2) the effects of a sustained focus on limited scale conflicts during the Global War on Terror (Berger, 2020). With the rise of conventional power and aggression from a great power state, and the winding down of the Global War on Terror as evidenced by the effective defeat of ISIL and a withdrawal of American troops from Afghanistan, the Marine Corps now has the catalyst it has so long lacked to renew a close partnership with the navy (Berger, 2020).

This is only at the service level within one of the branches of the United States military. At the national level, there is clear recognition of China as the principal security threat facing the United States today. The Trump administration's (2017) National Security Strategy mentions China a total of 33 times in its unclassified publication. The document is interesting in that it expresses regret that attempts to be inclusive and supportive of a developing China in hopes of assisting their liberalization have outright failed (p. 25). The Trump administration (2017) expresses the idea that China is aggressive and expansionist, and wholly "antithetical to U.S. values and interests" (p. 25). This is not entirely exclusive to the Trump administration. Although the new Biden administration has significantly different rhetoric than the previous president, the Interim National Security Strategic Guidance still views China as a growing rival (Biden, 2021, p. 6). Additionally, Biden (2021) has identified China as both "rapidly more assertive" and the single nation that is able to muster its national power to challenge the international system (p. 8).

The National Defense Strategy mentions China before it mentions any other country, and it does so at 
the beginning of the third paragraph of the introduction (DoD, 2018, p. 1). The NDS lumps China in together with Russia as states which are not following the "rules of the road", implying a sense of aggressive abandon that must be addressed (DoD, 2018, p. 2). Moreover, the Joint Chiefs of Staff level, National Military Strategy lists as the top two bullet points in its observed, global security trends: a reemergence of great power competition and a weakening of the post-World War Two order (Joint Chiefs of Staff, 2018, p. 2). Whether any of these assessments are completely accurate is beyond the scope of this study. What is clear is that the United States is increasingly becoming focused on China as a security threat, and identifies the conventional, maritime nature of potential conflict. As will be further demonstrated in later analysis of military shifts, the so-called "Asia Pivot" is real, extends beyond the Obama administration, and is only increasing.

\section{Current Capacities and Limitations}

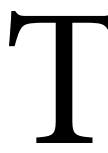

The United States has an immensely powerful navy. This is especially true when compared with the naval power of other prominent states across the world. However, it is wrong to accept the simple, paper depictions of the United States' naval power on the basis of its large volume of substantial warships. A navy's power is far more complex than simple ratios of vessels within a certain class range. As we will see, this is particularly true in the modern age. A more detailed look at the overall conditions will yield details that carry important implications for the state of the United States' military power in the context of a possible confrontation with China.

\section{Shipyards and Shipbuilding}

The United States was famously able to escalate a massive industrial war effort after entering hostilities during World War Two. Since the conflicts that comprised the war took place almost exclusively on different continents, its ability to project power across oceans was vitally important. The United States' opponents, however, were strong naval powers. Moving troops and materiel to Europe required running a gauntlet of U-boat hunting grounds which comprised a Battle of the Atlantic that lasted from before Americans were direct participants, to the conclusion of the war. In the Pacific, Imperial Japanese naval power was a fierce competitor with the United States in subsurface, surface, and air capabilities. This all translated to a need for enormous shipbuilding volumes. Although much has been written about the arguably ineffective attack on Pearl Harbor, it nonetheless succeeded in dealing a serious blow to a substantial portion of the U.S. Navy's capital ships.

The United States enjoyed important advantages that enabled it to successfully direct its industrial engine towards war. The idea that the United States' industrial shipbuilding capacity was a result of entering hostilities, however, is a myth. The fact is that political leadership was already in the process of setting the foundations for wartime 
production (DoT, n.d.). The Emergency Shipbuilding Program itself was stood up prior to the United States joining the war (DoT, n.d.). Moreover, it was the Emergency Shipbuilding Program that was responsible for the production of the majority of the vessels produced by the United States during the war (DoT, n.d.). By contrast, modern American shipbuilding is a hollow shell of its former figure (Klein, 2015). After World War Two, the United States was at peak shipbuilding and remained the dominant player in this industry for a few decades (Klein, 2015). By the 1970s, already declining production plummeted (Klein, 2015). This is owing to shipbuilding being effectively outsourced as other countries produced vessels more cheaply and invested government subsidies into the industry (Klein, 2015). Notably, China is one of the lead countries most outproducing the United States in shipbuilding (Klein, 2015).

If the United States were called upon today to launch the same level of ocean-shipped, material support to a beleaguered ally in the Pacific, it would not be able to replicate its previous success on the grounds of production limitations alone. This does not even account for the threats posed by China to American shipping at the outset of a conflict. Merchant shipping is important for its utility in war, as demonstrated by the experiences in World War Two. It also has the important effect of freeing up shipyards for producing warships. In this regard, the United States is also suffering from a decayed infrastructure (Riposo, et al., 2008).
The ability of United States Navy shipyards to even maintain existing fleets has been overstretched in recent years (Riposo, et al., 2008). Cost overruns and underestimations of demands on shipyards have been the standard in recent American history (Riposo, et al., 2008). As China's merchant and military shipbuilding production has been exploding across the modern, historical timeline, the United States has been shrinking and struggling to even maintain existing platforms. Inaccurately projected timelines for the mere maintenance of United States Navy ships has caused not only huge delays, but overtime work has become a consistent issue that contributes to the problem of unpredicted expenses piling up (Riposo, et al., 2008). With these enduring problems, should Congress be easily convinced that further additions to the fleets will be an effective expenditure of tax dollars?

Yet, this is exactly what Congress is being asked to do. The Trump administration backed an enormous increase in ship orders to expand the navy across the board, adding to an already backed up shipyard log (Eckstein, 2020). Plans from the office of the Secretary of Defense have called for an ambitious expansion and modernization of the navy (DoD, 2020). Concessions the navy has been willing to make include the retirement of about 10 of the larger, Ticonderoga class guided missile cruises and certain amphibious assault ships to make a degree of budgetary allowance for sweeping increases in warship production (Eckstein, 2020). The following graph depicts the scope of the changes: 


\section{Platform procurement projections in the FYDP}

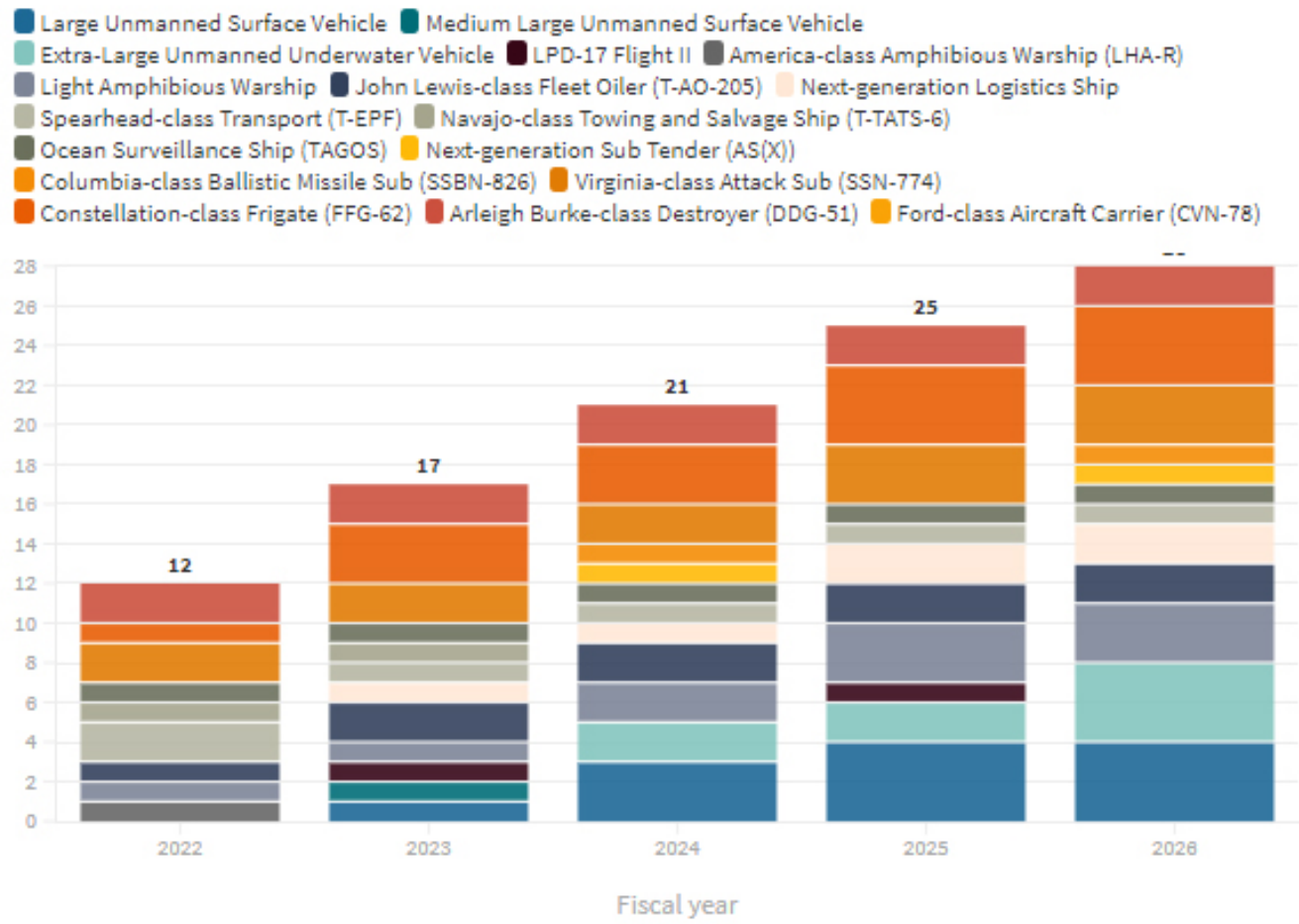

(Eckstein, 2020)

Notably, the navy is looking to return frigates to its fleets, which have been absent since the former Oliver Hazard Perry class frigates were sold for a supposed lack of relevance (Eckstein, 2020). In addition, the plans include other brand-new, concept ships such as unmanned vessels and Next-generation Logistics Ships (Eckstein, 2020). Meanwhile, lawmakers are aware that the navy's recent experiments in producing brand new lines of ships such as the Littoral Combat Ship, have resulted in vessels that the navy itself does not know what to do with (Eckstein, 2020). This is without even addressing the fate and plans for the failed Zumwalt class guided missile destroyers, which were intended to replace the Arleigh Burke class workhorses that comprise such a strong majority of American surface warfare combat power (Larter, 2021a).

The United States is trying to increase its number and types of warships, without increasing its already strained and gutted industrial capacity. Yet shipbuilding and acquisitions have been marked by broken processes and repeated failures (Larter, 2021a). If the navy were to find itself in a stand-up fight against a modern, Chinese navy, and sustain great losses, it would lack the infrastructure to quickly replace them. Moreover, production of vessels that the navy wants would need to be halted and re-tooled to replace the ships that it would now need. These are not optimistic conditions for entering a 
serious naval conflict with China. The United States, therefore, needs to look at alternatives.

\section{Distinct Advantages}

One area in which the United States has held a massive advantage over militaries around the world is in its navy. The disparity between American naval power in most of the modern era and that of any other country is difficult to overstate. As an illustration, China and the United Kingdom both have the second largest number of fully fledged aircraft carriers in the world, with two conventionally powered carriers in each country's navy (CSIS, 2020). The United States has 11, with all of them being nuclear-powered supercarriers, capable of deploying aircraft up to and including fixed wing fighters (USN, 2021). The overwhelming majority of surface combatants in world navies rank at the smaller frigate and corvette class of vessels (CSIS, 2020).

The smallest, primary surface warfare combatant in common usage with the United States Navy is the destroyer (USN, 2021). Once considered a smaller combatant, the destroyer is now the largest combatant in the majority of major navies around the world (CSIS, 2020). In the United States, the 329-crew destroyers are the primary workhorse of the fleets' "Anti-Air Warfare (AAW), Anti-Submarine Warfare (ASW), and Anti-Surface Warfare (ASuW)" missions (USN, 2021). The United States currently has a whopping 68 Arleigh Burke class guided missile destroyers in its fleets (USN, 2021). This is in addition to the two, newer and experimental Zumwalt class destroyers (USN, 2021). On top of this, the fleets currently possess 22 Ticonderoga class guided missile cruisers, even larger and more heavily armed than their destroyer counterparts (USN, 2021). American Littoral Combat Ships, which are an anomaly in world navies, are effectively comparable to corvettes although they were predominately meant to fulfil duties against asymmetric threats and have struggled to find relevance, particularly in conventional settings (USN, 2021).

However, a major part of the security problem posed by China has been the rapid and substantial modernization and expansion of the PLAN. The Center for Strategic and International Studies (2020) charts the current forces and the recent trends of their development across the leading navies of the world.

This chart illustrates the disparity in naval forces between the United States and other powers. While China's naval power has increased dramatically in recent years, this is predominately in the category of naval vessels that fall at or below the threshold of the destroyers. The United States maintains a clear advantage in vessels at the destroyer level and above, as well as aircraft carriers and amphibious assault ships (CSIS, 2020). While compelling, the chart does not depict the smaller classes of missile boats, which are capable of swarming large volumes of anti-ship missiles from a variety of short ranged, fast boats (Patch, 2010). Neither is it necessarily predictive of future trends, particularly 
with the uncertain fate of the aging U.S. warfare combatants that outclass the cruiser fleet, which represents a signif- Chinese navy (Larter, 2021c). icant portion of the powerful, surface
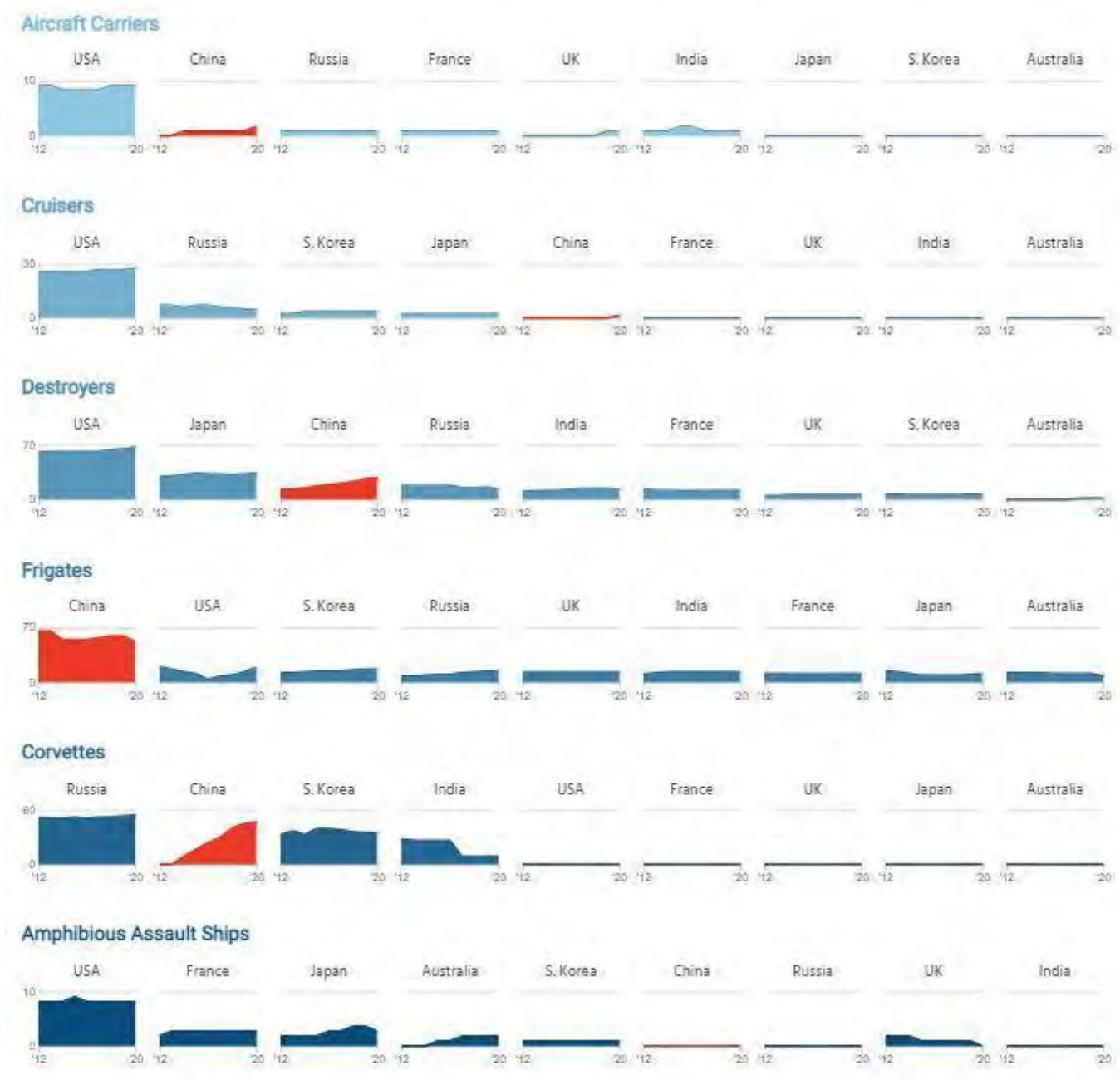

(CSIS, 2020)

Submarines are another category where the United States maintains a clear advantage over China (Berger, 2020). The United States operates exclusively nuclear-powered submarines, which are inherently more operationally useful by virtue of their long endurance (CSIS, 2020). By contrast, the overwhelming majority of Chinese submarines are diesel-electric vessels
(CSIS, 2020). It is this strong advantage that has led the Marine Corps to, in an unusual turn of military thought, identify subsurface warfare as a specific component for which Marine forces can potentially support and enhance naval power (Berger, 2020). Since existing force ratios, for all their advantages, have clearly not been sufficient to deter China from the disruptive encroach- 
ments for which it has gained attention, these types of conventional changes to military thinking are exactly what is called for to reshape, rather than simply enlarge, the United States military to better deter China.

\section{Changes to the United States Military}

There are many positive changes to the military that are currently happening. These changes should be sustained and built upon to shape the existing forces that the United States has into a more efficient tool of deterrence against China. These changes are characteristically low cost, and often can reduce costs by creating a leaner force rather than simply increasing the size. American defense spending is already massive (Chantrill, 2020). Moreover, it has been enormous for its entire modern history, even at its low points in between conflicts (Chantrill, 2020). Although the temptation to simply spend more money on defense in response to security threats or alarms, or to appease a constituency, might be strong, this does not solve security problems by itself. An already huge amount of defense spending must be focused first on reshaping and restructuring the military to modern threats, while having the discipline and fortitude to discard legacy systems and structures where they no longer enhance lethality.

The Commandant's Planning Guidance for the Marine Corps demonstrates sharp focus on the problem of China (HQMC, 2019). Much of the document's (2019) focus is given over to a radical transformation of the service to address conventional, and specifically naval threats. Because China is the only nation with a navy that can theoretically compete with the United States, it is clear that this attention is intended to address China. First, the document (2019) emphasizes the reintegration of the Marine Corps into more traditional partnerships with the navy (p. 4). Second, the force structure of the Marine Corps is massively overhauled (HQMC, 2019). This force structure change is drastic and unique in part because it calls for equipping Marines with anti-ship weapons, such as missiles, to combat conventional, naval forces (HQMC, 2019).

In addition to adding capabilities, the Marine Corps has determined to eliminate its force of tanks, parting ways with its Abrams Main Battle Tanks in favor of other assets (South, 2021). Tanks have been an integral part of the Marine Corps for close to a century, and their removal from the service is no small signal. The Marine Corps has chosen to become a smaller, more agile force that is meant to operate in small, isolated detachments in support of naval operations. The specific ways in which these changes have manifested indicates a clear focus on addressing the security problems of a naval conflict with China.

Marine Recon and Force Recon are small, elite forces that amount to a special operations force internal to the Marine Corps. These forces have recently begun training for specific missions that address this threat. 
Force Recon has resumed training with submarine-based insert capabilities (Thompson, 2021). From my own personal experience inside these organizations, I can attest that this is very unusual compared to the previous two decades of their work, and indicative of a clear shift in focus. Marine Recon has begun partnering with Air Force Special Operations Forces in training for Military Free Fall parachute operations to land specialized personnel onto remote islands, and rapidly facilitate the air landing of anti-ship missiles (Athey, 2021b). While I can assert from personal experience inside these Marine forces that partnership between Marine Recon and Special Operations Forces from sister services is not new, this specific mission set is a novel development.

The conventional Marine Corps has established other developments in this same vein. For example, the establishment of Marine Littoral Regiments, which are intended to enhance the Marine Corps' ability to complement and support naval efforts in the Pacific (Shelbourne, 2021). These changes are centered around the recent development of new doctrine for what is called Expeditionary Advanced Base Operations, which centers around Marine units operating in small, distributed networks of island forces that can provide defense and support to naval forces through a wide variety of means (Shelbourne, 2021). The Marine Corps has also spent the last few years investigating needed changes to its basic school of infantry, which has resulted in a massive expansion of the existing School of Infantry (Athey, 2021c). These changes emphasize a conventional threat and are a response to the shifts in refocusing the service to counter China (Athey, 2021a, 2021c). It is clear that the Marine Corps is attempting to redefine its infantry forces into more intelligent, capable individuals who are more effective at operating in small, autonomous teams without clear, structured directions by making foundational changes to a School of Infantry program that now looks radically different from the one I attended in 2010.

\section{Unacceptable Uncertainty}

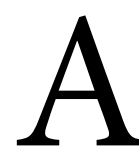

nother major limitation of military power as a coercive instrument against a rising China has nothing to do with the specific structure or forces of the United States military in comparison with China. As has been discussed, the previous experience of a naval conflict was World War Two. There have been no meaningful naval conflicts that have taken place since 1945. Altercations involving naval forces in the post-World War Two era have been miniscule. Minor actions such as the striking of USS Stark with Exocet missiles, and even those involving sinking vessels such as the Falklands War, are so small that they do not register as experiences from which serious, predictive knowledge can be wrought. This leaves us with the problem of theory. All concepts and plans for how a naval conflict with China would unravel, or could be won, are necessarily based on theoretical information.

Military technology has obviously undergone tremendous advancement 
since the close of World War Two. In the days of the last naval conflict, surface warfare combatants fought their peers with deck guns. Battleships and cruisers carried the most meaningful firepower in stand-up confrontations. The lightly armed but fast destroyers screened for the larger vessels and skirmished with volleys of shorter ranged, deck launched torpedoes that could channelize an opponent's movements, or quickly sink the unwary capital ship. Submarines forced ships into groups and necessitated smaller escort vessels that could chase down and depth charge the underwater vessels of the day, whose limited depth and slow speeds rendered them vulnerable once spotted, or once a ship in the convoy had been torpedoed. Naval airpower was the curve ball of the conflict, but one whose implications were quickly grasped.

World War Two was preceded by a substantial amount of near-term, naval experience. The massive Japanese victory at Tsushima kicked off the century, whereafter numerous, large scale naval actions took place. The developing trends of naval technology followed a relatively clear trajectory, along which the great powers were able to understand what made naval forces lethal and how they could compete. The Washington Naval Treaty of the inter-war period made its restrictions on the development of naval power based mostly on tonnages, which followed the general understanding that larger vessels with larger guns were the dominant expression of naval combat power (DoS, n.d.). Next to the complexity of naval forces today, naval combat power of the first half of the 20th century was comparatively formulaic.

The massive, 16-inch guns of World War Two dwarf the sparsely equipped, five-inch upper threshold of modern surface warfare combatants. Yet the 16-inch guns could not conceivably come within range of a modern destroyer or even frigate, with their arsenals of anti-ship missiles whose ability to engage targets is measured in hundreds of nautical miles or more. Additionally, the ability to counter these weapons is almost completely theoretical. Great powers today rely on lab tests, range tests, and the rare SINKEX in which naval forces tow condemned ships out to be test targets in heavily scripted scenarios (USN, n.d.). Moreover, the ordinance is extremely expensive and time consuming to replace compared to the simple sledgehammers of yesterday's deck guns.

Technical requirements for the employment of these weapons increase the 'moving parts' problem of the greater systems in and around them, which inherently increases the quantity of potential vulnerabilities. Countermeasures in the former days of naval action looked closer to a bloody game of dodgeball when contrasted with the innumerable countermeasures that are being explored for modern systems. These countermeasures run the gambit from Electronic Warfare to drones, from cyber to chaff. Missile defense systems range from anti-ballistic missiles, to CWIS guns, to directed energy systems. All of these systems and countermeasures operate on generally 
unproven grounds and have never been assessed in real world conflict beyond a limited number of isolated instances.

These are just the basic offensive and defensive systems. Naval forces today are increasingly equipped and augmented with a wide variety of other, emerging technologies. Unmanned systems are both taking to the skies and moving beneath the waves. In the realm of Unmanned Aircraft Systems (UAS), the United States is struggling to understand and counter emerging threats, which are exploding onto the scene in the hands of near-peer competitors and non-state actors alike (Mills, et al., 2021). UAS is demonstrating such a diverse array of capabilities, such as the suppression of enemy air defense systems in swarms, that their implications for conflict, particularly in the maritime domain, are still poorly understood by the United States (Mills, et al., 2021). Beyond this, services are pursuing entire vessels that are unmanned (Vavasseur, 2021). This is in addition to the already extensive, unmanned underwater systems that are already being tested and fielded (Larter, 2021c). The simple fact is that, in the modern age of naval technology, no matter how much money is invested in design and testing, militaries simply have no idea how a naval conflict would unfold, owing to the prevalence of technologies that have never been through a serious trial of combat.

\section{Other Instruments of Power}

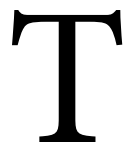

he limitations of military power in the case of the United States' objectives of countering a rising
Chinese security threat make it grossly unreliable for the standard framework of deterrence that has shown so much relevance and effectiveness most everywhere else. Elements of "soft power" must be preferred in engaging with China. The United States has numerous allies in the region with whom it has already established relationships and partnerships that may be built upon. Capitalizing on relationships and partnerships is key to the alternatives upon which unilateral, military power must hinge. In my own experience, military cooperation with Pacific-Asian military partners is commonplace across a span of allies. I have personally participated in combined training exercises in the Pacific with partners such as Japan, the Philippines, and South Korea. Whilst active duty in a maritime service for over a decade, I came to know partnerships with many other Pacific partners as routine.

However, I have found in my experience that many of these partnerships are "for the cameras" and lack the substantial integration that would be required at the ground level to successfully conduct combined operations in combat. The United States has much room to expand on its existing military partnerships beyond simply increasing their frequency. The depth of interaction and exchange is an important element of the partnerships that cannot be replaced. Moreover, it can be advertised to increase a sense of both deterrence through a balance of power and by creating a sense of self-exclusion. China's vacancy in these military partnerships with the United States and its Pacific 
allies is audible. This should be looked at as a diplomatic tool that could offer the Chinese a chance at both inclusion and recognition, and thereby a further incentive to distance itself from expansionist ambition. In other words, military matters are not exclusively a realist's tool for traditional deterrence. How they are undertaken can give them the capacity to carry normative weight.

In the case of alliances writ large, an unusual, but striking example can be seen in the experience of Great Britain during the Napoleonic Wars. Alliances were the vehicle by which Great Britain was finally able to defeat France (Flynn, 2021). It was the very same problem of the expansionist impulses of France that brought the two great powers into conflict (Flynn, 2021). Conflict occurred because of the upset to a comparatively fragile balance of powers on the European continent (Flynn, 2021). China does not benefit from the same level of eager cooperation from allies in the region as does the United States (Flynn, 2021). As Chinese aggression increases, especially as it manifests itself to the economic exclusion of its neighbors, it becomes increasingly alienated (Flynn, 2021).

The United States must enhance these partnerships because there is the real risk that the possibility of "internal woes" could lead China to rapidly become more expansionist as a means of state-preservation (Flynn, 2021). Great Britain's failure to emphasize these relationships and foster a sense of inclusion provided such a rallying cry for Napoleonic France (Flynn, 2021). It is around this problem that the prospects of peace and war may well hinge. There is a strong temptation for great powers to reach straight over a more moderate solution and grasp hegemony in the fashion of Mearsheimer's (2001) theories. However, this neglects the very remedy that could prevent war; the same remedy that would surely be reached for at the outset of hostilities to combat the problem that it could have contained. A balance of power, rather than outright hegemony, is the better preserver of peace with China (Flynn, 2021).

With regards to direct diplomacy, the United States must be willing to meet and negotiate with China wherever opportunities exist. Even the Trump administration, which was overtly hostile to China in its rhetoric, expressed a willingness to be ready to "cooperate across areas of mutual interest" with China (Trump, 2017, p. 25). This is vital to the success of the United States in dealing with China, and it must be prepared to make concessions to China in addition to negotiation along these areas of mutual interest. It is clear that Chinese territorial claims in the South China Sea carry an enormous amount of historical precedence (Gao \& Jia, 2013). This increases the need for the United States to cooperate with China, who may feel slighted by the more modern demarcations of international waters, over mineral and fishing access (Gao \& Jia, 2013). This will no doubt bring the United States into the role of a supporting arbiter between China and its neighbors. However, there is real reason to believe that China will be willing to cooperate rather than face the propo- 
sition of further alienating its neighbors and increasing the extent to which they entangle themselves in U.S. alliances. The United States has in recent years become increasingly adversarial with China (Nacht, 2018, p. 117). It must be a priority of the United States to engage with China on diplomatic grounds and reassure the country that it is harmonizing, rather than being bullied, into peaceful relationships on the international stage (Nacht, 2018).

\section{Conclusion}

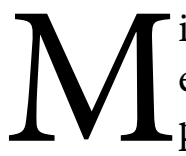

ilitary deterrence is a proven, viable concept, and has played a large role in successfully enhancing the security of the United States over its history. However, as even Mearsheimer (2001) notes, no theory has universal application or explanatory power (p. 10). The modern case of a rising, Chinese naval power is important in one respect because it is anomalous to general theories of military deterrence. That is, military deterrence is not currently effective in this case to the extent that it would normally be elsewhere. The United States must deemphasize it here and lean more heavily on other instruments. Nowhere in this study is it being suggested that the United States is currently engaging in a one-dimensional approach to the security problems posed by China. In fact, it is nowhere suggested here that the United States has ever had a strictly one-dimensional approach to security problems. Various methods and policies outside of military solutions have all had their hand in American conflicts and conflict prevention, just as they do today. Rather, the United States should more heavily favor these alternative instruments than it currently does.

There is evidence that, in some ways, the United States is on a good trajectory towards synthesizing these alternative instruments. The United States seeks cooperation with allies. Military partnerships are being engaged to a degree. International institutions have been sought to resolve disputes. Diplomacy has not yet failed. These elements are reassuring to an extent and should be pursued with increasing vigor. The United States has rough patches with its allies and military partners to smooth over. A new administration must prioritize these relationships and seek out the validation of international institutions to create a sense of Chinese self-exclusion that will encourage cooperation with the world rather than sacrificing the gains of friendship for those of some limited ambitions.

Moreover, many of the drastic changes to the United States military are indicative of a more thoughtful approach about leveraging military power, rather than the blunt-instrument solution of hammering the anvil with more money for ever-expanding forces. The United States must do more than maintain a strong military force, it must reshape the force to be calibrated against those threats which it has clearly identified. It must do so by reform that is puritanically practical, with a mind only to its lethality. It must not inflate its already enormous defense spending. Additionally, it must not orient this 
force in such an aggressive posture, nor coupled with such antagonistic messaging, that it overcomplicates the simpler arithmetic that a naked, powerful force presents. In this way, it can avoid "the sword drawn to prevent the drawing of swords," when "one sword keeps another in its sheath" (Heinl, 1966: Purchas, 1612; Herbert, 1651, pp. 246-247).

War with China is certainly not inevitable, and it is in everyone's mutual interest that it be prevented. The United States must exercise a preference for the other means at its disposal to encourage China to shy away from its alienating ambitions, and move towards the harmony that its own culture emphasizes. The British demonstrated a successful and resourceful use of alliances to counter an expansionist France. However, their policies emphasizing unilateral strength of arms failed to prevent the wars from taking place - peace was not had before sustained bloodshed. The United States recognized the rising threat of Imperial Japan decades before the attack on Pearl Harbor, and again peace was achieved through violence, this time on a more terrible scale. The story of American involvement in World War Two is often cherished as a great victory in a justifiable war. These narratives are only wrong if they provide a perverse inspiration to fight another justifiable one. Indeed, as with all forms of human conflict, pride and egos rear their selfish heads. We must humble them and choose a deliberate communication that prefers some notion of community, balanced with an awareness of the dark and unpredictable consequences for our failures in this great, globalizing challenge of reconciling foreign worlds.

Brendan Potter served for ten years on active duty in the Marine Corps between the Marine Raider, Marine Recon, and Force Recon communities. He is currently a graduate student in the Master of International Studies program at North Carolina State University. He holds a B.S in Strategic Studies and Defense Analysis. His primary area of research includes the broad challenges associated with the reemergence of Great Power competition. He welcomes opportunities for continued research and collaboration and can be reached at Brendan.M.Potter@gmail.com.

\section{References}

Athey, P. (2021a, January 3). New in 2021: Marine Corps to launch new infantry training program. Marine Corps Times. https://www.marinecorpstimes.com/news/ your-marine-corps/2021/01/03/new-in-2021-marine-corps-to-launch-new-in fantry-training-program/. 
Athey, P. (2021b, January 25). How the Air Force is making Marine recon better. Marine Corps Times. https://www.marinecorpstimes.com/news/marine-corpstimes/2021/01/21/how-the-air-force-is-making-marine-recon-better/.

Athey, P. (2021c, April 21). Here's what the corps' new school of infantry training looks like. Marine Corps Times. https://www.marinecorpstimes.com/news/yourmarine-corps/2021/04/21/heres-what-the-corps-new-school-of-infantry-train ing-looks-like/.

Berger, D. (Guest). (2020, December 7). Episode 198 - Commandant on Marines fighting subs [Audio podcast]. U.S. Naval Institute. https://www.usni.org/maga zines/proceedings/the-proceedings-podcast.

Biden, J. R. (2021, March). Interim national security strategic guidance. Whitehouse.gov. https://www.whitehouse.gov/wp-content/uploads/2021/03/NSC-1v2. pdf.

Chantrill, C. (2020, December 6). Defense spending. US Government Spending. https://www.usgovernmentspending.com/defense_spending.

CSIS. (2020, August 25). How is China modernizing its navy? ChinaPower Project. Center for Strategic and International Studies. https://chinapower.csis.org/chi na-naval-modernization/.

DoD (2018). Summary of the 2018 national defense strategy. Defense.gov. https:// dod.defense.gov/Portals/1/Documents/pubs/2018-National-Defense-Strate gy-Summary.pdf.

DoD. (2020, December 10). Statement from Deputy Secretary of Defense David L. Norquist on the Department of the Navy. U.S. Department of Defense. https:// www.defense.gov/Newsroom/Releases/Release/Article/2442969/statement-fromdeputy-secretary-of-defense-david-1-norquist-on-the-department-o/.

DoS. (n.d.). The Washington naval conference, 1921-1922. Office of the Historian. U.S. Department of State. https://history.state.gov/milestones/1921-1936/na val-conference.

DoT. (n.d.). The emergency shipbuilding program. The Emergency Shipbuilding Program | MARAD. https://www.maritime.dot.gov/multimedia/emergency-ship building-program.

Eckstein, B. M. (2020, December 10). Updated: White House-led navy shipbuilding plan set to push boundaries of Pentagon budgets, industry capacity. USNI News. 
https://news.usni.org/2020/12/10/white-house-led-navy-shipbuilding-plan-setto-will-push-boundaries-of-pentagon-budgets-industry-capacity.

Flynn, M. (2021, April 12). What Napoleon can teach us about the South China Sea. War on the Rocks. https://warontherocks.com/2021/04/what-napoleon-canteach-us-about-the-south-china-sea/.

Gao, Z., \& Jia, B. B. (2013). The nine-dash line in the South China Sea: History, Status, and Implications. American Journal of International Law, 107(1), 98-123. https://doi.org/10.5305/amerjintelaw.107.1.0098

Heinl, R. D. (1966). The dictionary of military and naval quotations. U.S. Naval Institute Press. Excerpts originally published in 1612 (Purchas, S.) and 1651 (Herbert, G.).

HQMC. (2019). Commandant's planning guidance. marines.mil. https://www.hqm c.marines.mil/Portals/142/Docs/\%2038th\%20Commandant\%27s\%20Planning \%20Guidance_2019.pdf?ver=2019-07-16-200152-700.

Joint Chiefs of Staff (2018). Description of the national military strategy 2018. jcs. mil. https://www.jcs.mil/Portals/36/Documents/Publications/UNCLASS_2018_ National_Military_Strategy_Description.pdf.

Klein, A. (2015). Decline in U.S. shipbuilding industry: A cautionary tale of foreign subsidies destroying U.S. jobs. enotrans.org. https://www.enotrans.org/article/decline-u-s-shipbuilding-industry-cautionary-tale-foreign-subsidies-destroy ing-u-s-jobs/.

Larter, D. B. (2021a, January 12). Here's the US Navy's plan to stop its string of shipbuilding failures. Defense News. https://www.defensenews.com/digital-show-dai lies/surface-navy-association/2021/01/11/heres-the-us-navys-plan-to-stop-itsstring-of-shipbuilding-failures/.

Larter, D. B. (2021b, February 18). With the submarine threat on the rise, the US Navy looks to autonomous water sensor drones. https://www.defensenews.com/ naval/2021/02/17/with-the-submarine-threat-on-the-rise-the-us-navy-looks-toautonomous-water-sensor-drones/.

Larter, D. B. (2021c, April 12). As the US Navy scrambles to field more missiles in Asia, a tough decision looms for aging cruisers. Defense News. https://www.de fensenews.com/naval/2021/04/12/as-the-us-navy-scrambles-to-field-more-mis siles-in-asia-a-tough-decision-looms-for-aging-cruisers. 
McCarthy, J. (2021, March 26). Chinese ship deployment roils south china sea. NPR. https://www.npr.org/2021/03/26/981668318/chinese-ship-deployment-roilssouth-china-sea

Mearsheimer, J. J. (2001). The tragedy of great power politics. New York, New York. W. W. Norton \& Company.

Mills, W., Phillips-Levine, D., \& Phillips-Levine, T. (2021, January 20). Air supremacy lost: An imminent danger for ground troops. U.S. Naval Institute. https:// www.usni.org/magazines/proceedings/2020/december/air-supremacy-lost-im minent-danger-ground-troops.

Nacht, M., Laderman, S., \& Beeston, J. (2018). U.S. competitive strategies and China. Livermore Papers on Global Security, 5. https://cgsr.llnl.gov/content/assets/ docs/CGSR-LivermorePaper5.pdf.

Patch, J. (2010). A thoroughbred ship-killer. U.S. Naval Institute. https://www.usni. org/magazines/proceedings/2010/april/thoroughbred-ship-killer

Riposo, J., Alkire, B., Schank, J. F., Arena, M. V., Kallimani, J. G., Blickstein, I., ... Grammich, C. A. (2008, December 8). U.S. Navy shipyards: An evaluation of workload- and workforce-management practices. RAND Corporation. https://www. rand.org/pubs/monographs/MG751.html.

South, T. (2021, March 25). Goodbye, tanks: How the Marine Corps will change, and what it will lose, by ditching its armor. Marine Corps Times. https://www.marine corpstimes.com/news/your-marine-corps/2021/03/22/goodbye-tanks-how-themarine-corps-will-change-and-what-it-will-lose-by-ditching-its-armor/.

Shelbourne, M. (2021, January 20). Marine Corps to stand up first Marine littoral regiment in FY 2022. USNI News. https://news.usni.org/2021/01/20/marinecorps-to-stand-up-first-marine-littoral-regiment-in-fy-2022.

Shultz, R. H. (2012). Strategic culture and strategic studies: An alternative framework for assessing al-Qaeda and the global jihad movement. Joint Special Operations University Press. JSOU Report 12-4. Retrieved from: https://www.hsdl.org/ ?abstract\&did=736066

Thompson, C. (2021, February 2). USS Ohio conducts joint operations with Marine Corps element near Okinawa. DVIDS. https://www.dvidshub.net/news/388401/ uss-ohio-conducts-joint-operations-with-marine-corps-element-near-okinawa.

Trump, D. J. (2017, December). National security strategy. Whitehouse.gov. 
https://trumpwhitehouse.archives.gov/wp-content/uploads/2017/12/NSS-Fi nal-12-18-2017-0905.pdf.

USN. (2021). Fact files. United States Navy. https://www.navy.mil/Resources/FactFiles.

USN. (n.d.). SINKEX. Naval Sea Systems Command. U.S. Navy. https://www.nav sea.navy.mil/Home/Team-Ships/NAVSEA-21/Inactive-Ships/SINKEX/.

Vavasseur, X. (2021, January 26). Metal shark developing long range USV for the U.S. Marine Corps. Naval News. https://www.navalnews.com/naval-news/2021/01/ metal-shark-developing-long-range-usv-for-the-u-s-marine-corps/. 